\title{
Infectivity of Leprosy Bacilli from Bone Marrow and Liver of Patients with Lepromatous Leprosy*
}

\author{
CHARLES C. SHEPARD $\dagger$ \\ Leprosy and Rickettsial Diseases Unit, \\ Center for Disease Control, \\ U.S. Department of Health, Education, and Welfare, \\ Atlanta, Georgia 30333, U.S.A. \\ A. B. A. KARAT $\ddagger$ \\ Scheffelin Leprosy Research Sanitorium, \\ Karigiri, via Katpadi, \\ North Arcot District, South India
}

\begin{abstract}
Specimens of bone marrow or liver were collected from patients with lepromatous leprosy at the same time that skin biopsy specimens were removed. The viability of the bacilli was measured by inoculation into mice. There were 20 bone marrow specimens, and infectivity for mice was present in all of the 16 that came from patients whose skin specimens contained bacilli infective for mice. The incubation period was shorter with skin specimens in 10 cases. It did not differ by more than 2 months except in 3 cases, and in all 3 it was shorter with skin specimens. Thus, although viable Myco. leprae were present in marrow, the evidence suggests that in most instances the proportion of viable bacilli was somewhat less than in skin.

Five liver specimens were studied similarly. The bacillary viability in these specimens appeared also to be somewhat less than in the skin specimens.

These results are consistent with the hypothesis that the primary site of bacillary multiplication in lepromatous leprosy is in the skin and nasal mucosa, and that the bacilli enter the bloodstream from these sites, to be removed by phagocytes of the bone marrow and liver and other members of the reticulo-endothelial system.
\end{abstract}

Leprosy is a disease primarily of the skin and peripheral nerves and, in the lepromatous form, of the nasal mucosa. In the lepromatous disease, the bilaterally symmetrical distribution of the lesions strongly suggests blood-borne spread, and Mycobacterium leprae may be demonstrated microscopically in the blood (reviewed in Hollmann, 1916). In this form of the disease Myco. leprae may also be present in la rge numbers in the spleen and liver; whether the bacilli multiply there or are merely scavenged from blood, or even if many of the bacilli there a re

* Received for publication 26 April, 1972.

$\dagger$ Request reprints from Charles C. Shepard, Chief, Leprosy and Rickettsial Diseases Unit, Virology Section, Center for Disease Control, Atlanta, Georgia 30333, U.S.A.

$\ddagger$ Present address: Church of South India Hospital, Bangalore Cantonement, Bangalore 2, Mysore State, India. 
viable, had not been known. Recently the viability of Myco. leprae in the blood of lepromatous patients was reported (Drutz and Levy, 1971). The natural disease affects the cooler parts of the skin and the nerves preferentially, and in the experimental disease the bacilli grow in the cooler tissues of the mouse. Much evidence suggests that the optimum temperature for the multiplication of $M y c 0$. leprae is below $37^{\circ} \mathrm{C}$, probably about $30^{\circ}$, and that multiplication ceases near $37^{\circ}$ (reviewed in Shepard, 1965).

In the present study, we have employed mouse inoculations to compare the viability of $M y c($. leprae in lepromatous patients' bone marrow and liver specimens, with that in skin biopsy specimens taken at the same time.

\section{Materials and Methods}

The specimens were collected from patients with lepromatous leprosy at the Schieffelin Leprosy Research Sanitorium, Karigiri, near Vellore, South India. The patients were supposedly untreated, but determinations of the sulfone level in the plasma of a number of the patients showed that some had recently ingested dapsone. The specimens were flown to Atlanta under wet ice refrigeration. Usually the mouse inoculations were completed within $90 \mathrm{~h}$ of the time the specimens were collected.

The methods for mouse inoculation (Shepard, 1962) and counting of bacilli (Shepard and McRae, 1968) have been previously described. The skin and liver specimens were made into tissue suspensions as described by Shepard (1962). The bone marrow specimens, 2 to $4 \mathrm{ml}$ in volume, were diluted with distilled water to $5.0 \mathrm{ml}$, treated in the Mickle tissue disintegrator for $1 \mathrm{~min}$ with vibrations of $3 \mathrm{~mm}$ amplitude and centrifuged at $3000 \mathrm{rev} / \mathrm{min}$ (1200 g) for $30 \mathrm{~min}$; the supernatants were discarded; the sediments were resuspended in $5 \mathrm{ml}$ of distilled water, mixed thoroughly with a bulb and pipette, and recentrifuged at $3000 \mathrm{rev} / \mathrm{min}$; the supernatants were again discarded, and the sediments resuspended finally in a $2.0 \mathrm{ml}$ Hanks' balanced salt solution containing $0.1 \%$ bovine albumin. Because many red blood cells were still present in the final suspensions, the slides had to be de-stained for a longer period than was necessary for the suspensions of skin and liver specimens. All suspensions were diluted, if necessary, to contain $5.0 \times 10^{3}$ acid-fast bacilli in the $0.03 \mathrm{ml}$ inoculated into mice. The extra de-staining of bone-marrow specimens appears to have led to an underestimate of the number of bacilli inoculated into mice.

After inoculation, one mouse was killed each month for histological sections; the time elapsed before acid-fast bacilli appeared in histological sections is referred to as the incubation period. The figure for the incubation period was taken as a measure of the proportion of viable bacilli in the inoculum. If the number of bacilli from marrow specimens was, in fact, underestimated, the incubation period would have been shortened and the viability of marrow bacilli overestimated.

When acid-fast bacilli in significant numbers were observed in the histological sections, 4 mice were killed for counts of bacilli in their harvested footpad tissues. The number of bacilli harvested per mouse is presented in Table 1, and this gives an indication of timing of the harvests. The generation time was not used to estimate viability because this figure was affected excessively by underestimation of the inoculum. 
TABLE 1

Infec tivity of leprosy bacillifrom skin, bone marrow and liver of patients with lepromatous lepros $y^{a}$

\begin{tabular}{|c|c|c|c|c|c|}
\hline Patient & Material $^{a}$ & $\begin{array}{c}\mathrm{AFB}^{b} \\
\text { recovered }\end{array}$ & $\begin{array}{c}\mathrm{AFB} \\
\text { inoculated }\end{array}$ & $\begin{array}{c}\text { Incubation } \\
\text { period } \\
\text { (mos.) }\end{array}$ & $\mathrm{H}^{c}$ \\
\hline 8578 & $\begin{array}{l}\mathrm{S} \\
\mathrm{M}\end{array}$ & $\begin{array}{r}9.7 \times 10^{5} \\
<\quad 7 \times 10^{4}\end{array}$ & $\begin{array}{r}5.0 \times 10^{3} \\
<\quad 1 \times 10^{3}\end{array}$ & $\begin{array}{l}6 \\
6\end{array}$ & $\begin{array}{l}4.6 \times 10^{4} \\
8.0 \times 10^{4}\end{array}$ \\
\hline 9841 & $\begin{array}{l}\mathrm{S} \\
\mathrm{M}\end{array}$ & $\begin{array}{l}3.5 \times 10^{7} \\
2.5 \times 10^{5}\end{array}$ & $\begin{array}{l}5.0 \times 10^{3} \\
3.7 \times 10^{3}\end{array}$ & $\begin{array}{l}4 \\
6\end{array}$ & $\begin{array}{l}6.8 \times 10^{5} \\
2.2 \times 10^{5}\end{array}$ \\
\hline 9853 & $\begin{array}{l}\mathrm{S} \\
\mathrm{M}\end{array}$ & $\begin{array}{l}2.1 \times 10^{7} \\
2.3 \times 10^{8}\end{array}$ & $\begin{array}{l}5.0 \times 10^{3} \\
5.0 \times 10^{3}\end{array}$ & $\begin{array}{l}4 \\
9\end{array}$ & $\begin{array}{l}1.3 \times 10^{5} \\
2.8 \times 10^{5}\end{array}$ \\
\hline 9949 & $\begin{array}{l}\mathrm{S} \\
\mathrm{M}\end{array}$ & $\begin{array}{l}1.1 \times 10^{4} \\
<4 \times 10^{2}\end{array}$ & $\begin{array}{l}1.1 \times 10^{3} \\
<6 \times 10^{2}\end{array}$ & $\begin{array}{l}>12 \\
>12\end{array}$ & $\begin{array}{l}\text { Not done } \\
\text { Not done }\end{array}$ \\
\hline 9972 & $\begin{array}{l}\mathrm{S} \\
\mathrm{M}\end{array}$ & $\begin{array}{l}3.6 \times 10^{8} \\
5.8 \times 10^{5}\end{array}$ & $\begin{array}{l}5.0 \times 10^{3} \\
5.0 \times 10^{3}\end{array}$ & $\begin{array}{l}6 \\
5\end{array}$ & $\begin{array}{l}2.2 \times 10^{6} \\
4.4 \times 10^{5}\end{array}$ \\
\hline 9974 & $\begin{array}{l}\mathrm{S} \\
\mathrm{M}\end{array}$ & $\begin{array}{l}4.8 \times 10^{6} \\
5.1 \times 10^{5}\end{array}$ & $\begin{array}{l}5.0 \times 10^{3} \\
5.0 \times 10^{3}\end{array}$ & $\begin{array}{l}8 \\
9\end{array}$ & $\begin{array}{l}7.8 \times 10^{5} \\
9.8 \times 10^{4}\end{array}$ \\
\hline 9976 & $\begin{array}{l}\mathrm{S} \\
\mathrm{M}\end{array}$ & $\begin{array}{l}2.8 \times 10^{7} \\
2.1 \times 10^{5}\end{array}$ & $\begin{array}{l}5.0 \times 10^{3} \\
3.1 \times 10^{3}\end{array}$ & $\begin{array}{l}>12 \\
>12\end{array}$ & $\begin{array}{l}\text { Not done } \\
\text { Not done }\end{array}$ \\
\hline 9978 & $\begin{array}{l}\mathrm{S} \\
\mathrm{M}\end{array}$ & $\begin{array}{l}4.1 \times 10^{7} \\
3.1 \times 10^{5}\end{array}$ & $\begin{array}{l}5.0 \times 10^{3} \\
4.7 \times 10^{3}\end{array}$ & $\begin{array}{l}6 \\
6\end{array}$ & $\begin{array}{l}2.9 \times 10^{5} \\
3.4 \times 10^{5}\end{array}$ \\
\hline 9979 & $\begin{array}{l}\mathrm{S} \\
\mathrm{M}\end{array}$ & $\begin{array}{l}4.9 \times 10^{7} \\
2.0 \times 10^{6}\end{array}$ & $\begin{array}{l}5.0 \times 10^{3} \\
5.0 \times 10^{3}\end{array}$ & $\begin{array}{l}5 \\
6\end{array}$ & $\begin{array}{l}1.3 \times 10^{5} \\
1.8 \times 10^{5}\end{array}$ \\
\hline $9980^{d}$ & $\begin{array}{l}\mathrm{S} \\
\mathrm{M}\end{array}$ & $\begin{array}{l}4.1 \times 10^{7} \\
3.1 \times 10^{6}\end{array}$ & $\begin{array}{l}5.0 \times 10^{3} \\
5.0 \times 10^{3}\end{array}$ & $\begin{array}{l}6 \\
7\end{array}$ & $\begin{array}{l}1.7 \times 10^{6} \\
1.2 \times 10^{5}\end{array}$ \\
\hline 10014 & $\begin{array}{l}\mathrm{S} \\
\mathrm{M}\end{array}$ & $\begin{array}{r}1.1 \times 10^{8} \\
<1.7 \times 10^{5}\end{array}$ & $\begin{array}{r}5.0 \times 10^{4} \\
<2.6 \times 10^{3}\end{array}$ & $\begin{array}{l}5 \\
7\end{array}$ & $\begin{array}{l}4.0 \times 10^{5} \\
5.3 \times 10^{5}\end{array}$ \\
\hline 10066 & $\begin{array}{l}\mathrm{S} \\
\mathrm{M}\end{array}$ & $\begin{array}{r}2.7 \times 10^{7} \\
<1.8 \times 10^{5}\end{array}$ & $\begin{array}{r}5.0 \times 10^{3} \\
<2.7 \times 10^{3}\end{array}$ & $\begin{array}{l}5 \\
5\end{array}$ & $\begin{array}{r}3.9 \times 10^{5} \\
9 \times 10^{4}\end{array}$ \\
\hline 10073 & $\begin{array}{l}\mathrm{S} \\
\mathrm{M}\end{array}$ & $\begin{array}{r}8 \times 10^{4} \\
1.8 \times 10^{5}\end{array}$ & $\begin{array}{l}1.2 \times 10^{3} \\
2.5 \times 10^{3}\end{array}$ & $\begin{array}{l}7 \\
6\end{array}$ & $\begin{array}{l}1.6 \times 10^{5} \\
2.2 \times 10^{5}\end{array}$ \\
\hline 10079 & $\begin{array}{l}\mathrm{S} \\
\mathrm{M}\end{array}$ & $\begin{array}{l}1.0 \times 10^{6} \\
9.8 \times 10^{5}\end{array}$ & $\begin{array}{l}5.0 \times 10^{3} \\
5.0 \times 10^{3}\end{array}$ & $\begin{array}{l}>12 \\
>12\end{array}$ & $\begin{array}{l}\text { Not done } \\
\text { Not done }\end{array}$ \\
\hline $10121^{e}$ & $\begin{array}{l}\mathrm{S} \\
\mathrm{M}\end{array}$ & $\begin{array}{l}<4 \times 10^{4} \\
<2 \times 10^{5}\end{array}$ & $\begin{array}{l}<6 \times 10^{2} \\
<3 \times 10^{3}\end{array}$ & $\begin{array}{l}>12 \\
>12\end{array}$ & $\begin{array}{l}\text { Not done } \\
\text { Not done }\end{array}$ \\
\hline 10125 & $\begin{array}{l}\mathrm{S} \\
\mathrm{M}\end{array}$ & $\begin{array}{l}3.7 \times 10^{6} \\
<2 \times 10^{5}\end{array}$ & $\begin{array}{l}5.0 \times 10^{3} \\
<3 \times 10^{3}\end{array}$ & $\begin{array}{l}5 \\
\cdot \quad 9\end{array}$ & $\begin{array}{l}4.1 \times 10^{5} \\
3.2 \times 10^{5}\end{array}$ \\
\hline 10127 & $\begin{array}{l}\mathrm{S} \\
\mathrm{M}\end{array}$ & $\begin{array}{l}4.1 \times 10^{7} \\
1.8 \times 10^{6}\end{array}$ & $\begin{array}{l}5.0 \times 10^{3} \\
5.0 \times 10^{3}\end{array}$ & $\begin{array}{l}6 \\
8\end{array}$ & $\begin{array}{l}1.1 \times 10^{6} \\
6.1 \times 10^{4}\end{array}$ \\
\hline 10128 & $\begin{array}{l}\mathrm{S} \\
\mathrm{M}\end{array}$ & $\begin{array}{l}1.5 \times 10^{7} \\
<2 \times 10^{5}\end{array}$ & $\begin{array}{l}5.0 \times 10^{3} \\
<3 \times 10^{3}\end{array}$ & $\begin{array}{l}6 \\
5\end{array}$ & $\begin{array}{l}1.8 \times 10^{5} \\
2.3 \times 10^{4}\end{array}$ \\
\hline 10135 & $\begin{array}{l}\mathrm{S} \\
\mathrm{M} \\
\mathrm{L}\end{array}$ & $\begin{array}{l}1.3 \times 10^{6} \\
<2 \times 10^{5} \\
1.6 \times 10^{6}\end{array}$ & $\begin{array}{l}5.0 \times 10^{3} \\
<3 \times 10^{3} \\
5.0 \times 10^{3}\end{array}$ & $\begin{array}{l}6 \\
7 \\
7\end{array}$ & $\begin{array}{l}9.3 \times 10^{5} \\
1.9 \times 10^{5} \\
1.8 \times 10^{5}\end{array}$ \\
\hline 10138 & $\begin{array}{l}\mathrm{S} \\
\mathrm{M}\end{array}$ & $\begin{array}{l}4.6 \times 10^{5} \\
<3 \times 10^{5}\end{array}$ & $\begin{array}{l}5.0 \times 10^{3} \\
<4 \times 10^{2}\end{array}$ & $\begin{array}{r}5 \\
10\end{array}$ & $\begin{array}{r}2.6 \times 10^{5} \\
8 \times 10^{4}\end{array}$ \\
\hline 4198 & $\begin{array}{l}\mathrm{S} \\
\mathrm{L}\end{array}$ & $\begin{array}{l}6.0 \times 10^{6} \\
<4 \times 10^{4}\end{array}$ & $\begin{array}{l}5.0 \times 10^{3} \\
<5 \times 10^{2}\end{array}$ & $\begin{array}{r}5 \\
>12\end{array}$ & $\begin{array}{l}9.8 \times 10^{5} \\
\text { Not done }\end{array}$ \\
\hline
\end{tabular}


TABLE 1-Continued

\begin{tabular}{cccccc}
\hline Patient & Material & $\begin{array}{c}\mathrm{AFB}^{b} \\
\text { recovered }\end{array}$ & $\begin{array}{c}\mathrm{AFB} \\
\text { inoculated }\end{array}$ & $\begin{array}{c}\text { Incubation } \\
\text { period } \\
(\text { mos.) }\end{array}$ & $\mathrm{H}^{c}$ \\
\hline \multirow{2}{*}{9266} & $\mathrm{~S}$ & $3.1 \times 10^{7}$ & $5.0 \times 10^{3}$ & $>12$ & Not done \\
& $\mathrm{L}$ & $4.9 \times 10^{5}$ & $5.0 \times 10^{3}$ & 10 & $3.5 \times 10^{4}$ \\
10263 & $\mathrm{~S}$ & $4.0 \times 10^{6}$ & $5.0 \times 10^{3}$ & 10 & $4.4 \times 10^{5}$ \\
& $\mathrm{~L}$ & $1.9 \times 10^{6}$ & $5.0 \times 10^{3}$ & $>12$ & Not done \\
10265 & $\mathrm{~S}$ & $3.4 \times 10^{7}$ & $5.0 \times 10^{3}$ & 5 & $4.7 \times 10^{5}$ \\
& $\mathrm{~L}$ & $1.3 \times 10^{6}$ & $5.0 \times 10^{3}$ & 6 & $7.6 \times 10^{5}$ \\
\hline
\end{tabular}

${ }^{a} \mathrm{~S}=$ skin biopsy, $\mathrm{M}=$ bone marrow and $\mathrm{L}=$ liver specimen.

${ }^{b} \mathrm{AFB}=$ acid-f ast bacteria.

$c^{c} \mathrm{H}=\mathrm{AFB}$ harvested per mouse.

${ }^{d}$ Patient's serum contained $0.6 \mu \mathrm{g}$ dapsone $/ \mathrm{ml}$.

${ }^{e}$ Patient's serum contained $1.1 \mu \mathrm{g}$ dapsone $/ \mathrm{ml}$.

\section{Results}

\section{BONE MARROW SPECIMENS}

The detailed results are given in Table 1 . Of the 20 bone-marrow specimens, 11 contained countable numbers of acid-fast bacilli. The bone-marrow specimens were much larger than the skin specimens, so the concentration of observed bacilli in skin specimens was always greater. Patients with high numbers of bacilli in their skin specimens tended to have higher bacillary counts in their bone-marrow specimens (Table 2). The prolonged de-staining that was usually necessary with

TABLE 2

Relationship between number of bacilli in bone marrow and in skin specimens

\begin{tabular}{ll}
\hline \multicolumn{1}{c}{$\begin{array}{c}\text { AFB in skin } \\
\text { specimens }\end{array}$} & \multicolumn{1}{c}{$\mathrm{AFB}^{a}$ in bone marrow specimens } \\
\hline$<4 \times 10^{4}$ to $1.1 \times 10^{6}$ & $-{ }^{\mathrm{b}},-,-,-, 1.8 \times 10^{5}, 9.8 \times 10^{5}$ \\
$1.1 \times 10^{6}$ to $3 \times 10^{7}$ & $-,-,-,-, 2.1 \times 10^{5}, 5.1 \times 10^{5}, 2.3 \times 10^{6}$ \\
$3 \times 10^{7}$ to $4 \times 10^{8}$ & $-, 2.5 \times 10^{5}, 3.1 \times 10^{5}, 5.8 \times 10^{5}, 1.8 \times 10^{6}, 2.0 \times 10^{6}, 3.1 \times 10^{6}$ \\
\hline${ }^{a} \mathrm{AFB}=$ acid-fast bacteria. \\
$b_{- \text {signifies that no AFB were detected during the counting procedure. }}$
\end{tabular}

bone-marrow specimens may have led to frequent underestimation of the number of bacilli in this material. Of the 9 marrow specimens with negative bacillary counts, 7 were infective for mice, usually with incubation periods about as short as those for the corresponding skin specimen; the 2 that were not infective for mice came from patients whose skin specimens were also not infective for mice.

Infectivity for mice was present in all 16 bone-marrow specimens from patients whose skin bacilli were infective. The infectivity of skin and marrow bacilli is compared in Table 3. The incubation periods were shorter with skin specimens in 10 of 16 patients. They did not, however, differ by more than 2 months, except 
TABLE: 3

Proportion of viable bacilli in skin compared with bone marrow or liver, as judged by the incubation periods of the bacillary multiplication in mice

\begin{tabular}{ccc}
\hline \multicolumn{3}{c}{ Incubation period with skin specimens } \\
Shorter & Same & Longer \\
\hline Bone marrow & & \\
$9841^{a, b}$ & $8578^{c}$ & $9972^{b}$ \\
$9853^{b}$ & $9978^{b}$ & $10079^{b}$ \\
$9974^{b}$ & $10073^{c}$ & $10128^{c}$ \\
$9979^{b}$ & & \\
$9980^{b}$ & & \\
$10066^{c}$ & & \\
$10125^{c}$ & & \\
$10127^{b}$ & & \\
$10135^{c}$ & & \\
$10138^{c}$ & & \\
$10135^{b}$ & \\
$4198^{c}$ & \\
$10263^{b}$ & \\
$10265^{b}$ & \\
\hline
\end{tabular}

\footnotetext{
${ }^{a}$ Patient's number.

${ }^{b}$ The calculated bacillary inoculum from the two specimens being compared did not differ by more than twofold.

${ }^{c}$ The calculated inoculum from the skin specimens exceeded that from the other specimen by more than twofold.
}

in 3 patients $(9853,10125$, and 10138); in these 3 cases the incubation period was shorter with the skin specimen. The incubation period was shorter with the marrow specimen in 3 instances, but the difference here was only 1 month. Thus it seems quite possible that the proportion of viable bacilli present in marrow specimens never exceeded that in skin specimens. Some reservation is needed here, however, because the marrow bacilli received more manipulation before they were inoculated into mice.

\section{LIVER SPECIMENS}

The results are shown in Tables 1 and 3. The liver specimens were much smaller than the skin specimens; thus the concentration of bacilli in 2 of the liver specimens (10135 and 10263) may have been at least as high as that in their corresponding skin specimens. Of the 5 specimens inoculated in to mice, 4 contained countable numbers of bacilli. Of these, 2 gave incubation periods of 6 and 7 months respectively, only 1 month longer than that given by the same patient's skin specimen. In the other 2 cases, the results indicated that only a few viable bacilli were present in either skin or liver specimen (an incubation period as long as 10 months is observed in cases where only a few viable bacilli are inoculated and only a fraction of the mice develop infections). Thus the results with liver specimens, although limited, are similar to those with marrow specimens. The experimental treatment of liver bacilli was the same as that of skin bacilli. 


\section{Discussion}

Significant numbers of Myco. leprae were microscopically detectable in bone-marrow and liver specimens. Mouse inoculations demonstrated that viability was usually present, but indicated that in most instances the proportion of viable bacilli was probably less in bone-marrow and liver bacilli than in skin bacilli. If the bacilli in marrow and liver multiply at the same rate as those in skin, they might be expected to have infectivity equal to that of skin bacilli. An exact model of the multiplication of Myco. leprae in various tissues and its transport in blood cannot be constructed, however, because of missing information, for example the bacillary death rates and rates of disappearance of dead bacilli in bone marrow are not known. Nevertheless, the available results are in accord with the hypothesis that the primary site of multiplication of $M y c o$. leprae is in the cooler peripheral tissues. The high rates of blood flow through the skin and nasal mucosa at warm air temperatures would facilitate entry of the bacilli into the blood, and removal of blood-borne bacilli by phagocytes of bone marrow and liver would be in accord with the known function of these components of the reticulo-endothelial system.

An immunological rôle of leprosy bacilli in bone marrow seems possible. Bone marrow lymphocytes are processed in the thymus gland before they become T-lymphocytes, the mediators of cellular immunity. Much evidence suggests that immunity to leprosy and most other mycobacterial diseases is primarily a function of cellular immunity. The presence of living and dead Myco. leprae in the bone marrow of the lepromatous patient might inhibit the development of the clone(s) of lymphocytes destined, after processing in the thymus, to acquire the ability to develop sensitivity to $M y c o$. leprae. A deficiency of such cells might then lead to the tissue unresponsiveness for Myco. leprae that characterizes the lepromatous form of the disease.

The evidence for a low temperature optimum for multiplication for Myco. leprae has led to suggestions that, as a therapeutic measure, the temperature of involved tissue be raised by the local application of warm clothing or heat. A low temperature optimum for multiplication does not, however, necessarily signify that raising the temperature a few degrees above the optimum will lead to significant killing of the organisms or to their more rapid disappearance from the tissues. The present results do not encourage the use of local heat to kill Myco. leprae. Standard dosages of drugs are able to accomplish killing more rapidly; dapsone usually renders skin bacilli non-infective for mice in less than 100 days (Shepard, Levy, and Fasal, 1968), and rifampin in a few days (Shepard, Levy, and Fasal, 1972).

\section{Ref erences}

Drutz, D. and Levy, L. (1971). Further studies of leprosy bacteremia. Clin. Res. 19, 457.

Hollmann, H. T. (1916). B. leprae in the circulating blood of lepers. Pub. Hlth Bulletin 75, 15. Shepard, C. C. (1965). Stability of Mycobacterium leprae and temperature optimum for growth. Int. J. Lepr. 33, 541.

Shepard, C. C. (1962). Multiplication of Mycobacterium leprae in the footpad of the mouse. Int. J. Lepr. 30, 291.

Shepard, C. C. and McRae, D. H. (1968). A method for counting acid-fast bacteria. Int. J. Lepr. $36,78$.

Shepard, C. C., Levy, L. and Fasal, P. (1968). The death of Mycobacterium leprae during treatment with 4,4'-diamino-diphenylsulfone (DDS). Am. J. Trop. Med. Hyg. 17, 769.

Shepard, C. C., Levy, L. and Fasal, P. (1972). Rapid bactericidal effect of rifampin on Mycobacterium leprae. Am. J. Trop. Med. Hyg. 21, 446. 